DOI: https://doi.org/10.34883/PI.2021.10.3.003

UDC 616.345-089-072.1:615.849.19-035

Buhtarevich S. ${ }^{1}$, Denisenko V., ${ }^{1,}$, Gain Yu. ${ }^{3}$

1 Vitebsk Regional Clinical Specialized Center, Vitebsk, Belarus

${ }^{2}$ Vitebsk State Order of Peoples' Friendship Medical University, Vitebsk, Belarus

${ }^{3}$ Belarusian Medical Academy of Postgraduate Education, Minsk, Belarus

Бухтаревич С.П. ', Денисенко В.Л. ${ }^{1,2}$, Гаин Ю.М. ${ }^{3}$

${ }^{1}$ Витебский областной клинический специализированный центр, Витебск, Беларусь

${ }^{2}$ Витебский государственный ордена Дружбы народов медицинский университет,

Витебск, Беларусь

${ }^{3}$ Белорусская медицинская академия последипломного образования, Минск, Беларусь

\title{
Experimental Choice of the Regime of the Targeted Impact of High-Intensive Laser Radiation in Endoscopic Interventions on the Colon
}

\author{
Экспериментальный выбор режима целевого \\ воздействия высокоинтенсивного лазерного излучения \\ при эндоскопических вмешательствах на толстой кишке
}

Abstract

Introduction. The literature lacks a unified methodology for safe use of various laser systems for endoscopic devitalization of epithelial neoplasms. No sources were found, where the experimental development of laser coagulation of the colon would be performed in conditions as close as possible to clinical conditions (during intraluminal endoscopy).

Purpose. To evaluate the coagulating properties of various parameters of high-intensity laser radiation with the wavelength of $1.06-1.34 \mu \mathrm{M}$ in animal testing, to work out the optimal modes of safe intraluminal laser exposure to the rectal and colon mucosa in animal testing.

Materials and methods. The authors of the article carried out the experiment on laboratory animals (rabbits), which was aimed at the development of optimal modes of laser influence on intestinal tissues. The depth of the lesion of the intestinal wall was studied depending on the power of laser radiation in a constant time of remote exposure. There were selected the optimal parameters of safe mode of laser destruction of neoplasms of the colon mucosa during endoscopic intervention.

Results. In the course of the experiment, it was shown that the dose of laser radiation with a wavelength of $1.34 \mu \mathrm{m}$ (power $-15 \mathrm{~W}$, exposure -2 seconds) is sufficient and optimal for destruction of tumor tissue of the mucous membrane, limiting the zone of destruction with only mucous membrane, without thermal damage to the muscular layer of the intestinal membrane.

Conclusions. Experimental in vivo evaluation of various modes of exposure of high-intensity laser radiation on the colon mucosa allows predicting adverse outcomes of thermal ablation of benign tumors in clinical settings and establishing effective and safe modes of exposure.

Keywords: villous tumor, rectal and colon polyps, laser destruction, thermal ablation. 
Введение. В литературе отсутствует единая методология безопасного использования различных лазерных систем для эндоскопической девитализации эпителиальных новообразований, не найдено источников, в которых экспериментальная отработка режима лазерной коагуляции толстой кишки выполнялась бы в условиях, максимально приближенных к клиническим (во время внутрипросветной эндоскопии).

Цель. В эксперименте на лабораторных животных оценить коагулирующие свойства различных параметров высокоинтенсивного лазерного излучения длиной волны 1,06-1,34 мкм, отработать оптимальные режимы безопасного внутрипросветного лазерного воздействия на слизистую прямой и ободочной кишки в эксперименте на животных.

Материалы и методы. Авторами статьи проведен эксперимент на лабораторных животных (кроликах), направленный на отработку оптимальных режимов лазерного воздействия на ткани кишечника. Изучена глубина поражения стенки кишки в зависимости от мощности лазерного излучения при постоянном времени дистанционного воздействия, выбраны оптимальные параметры безопасного режима лазерной деструкции новообразований слизистой толстой кишки во время эндоскопического вмешательства.

Результаты. В ходе выполненного эксперимента показано, что доза лазерного излучения длиной волны 1,34 мкм (мощность 15 Вт, экспозиция 2 секунды) является достаточной и оптимальной для деструкции тканей опухоли слизистой, ограничивая зону деструкции только слизистой оболочкой, без термального повреждения мышечного слоя кишки.

Выводы. Экспериментальная оценка in vivo различных режимов воздействия высокоинтенсивного лазерного излучения на слизистую толстой кишки позволяет прогнозировать неблагоприятные исходы термальной абляции доброкачественных опухолей в клинических условиях, установить эффективные и безопасные режимы воздействия.

Ключевые слова: ворсинчатая опухоль, полип прямой и ободочной кишки, лазерная деструкция, термальная абляция.

\section{- INTRODUCTION}

At present, there are not any conservative methods for the treatment of polyps and villous adenomas of the colon, only the removal of the lesions (by surgery or destruction with the use of thermal ablation technology) can guarantee the success of the treatment. Timely removal of benign colon neoplasms helps to reduce the incidence of colorectal cancer by almost $80 \%$, as the risk of malignancy increases with an increase in the size of polyps (statistical indicators: $1 \mathrm{~cm}$ - less than $1 \%, 1-2 \mathrm{~cm}-9.5 \%$, more than $2-\mathrm{cm} 46 \%)[1,2]$. In the arsenal of an endoscopist, polypectomy remains the most common intervention for villous tumors and colon polyps $[3,4]$. Electroexcision technologies, the use of electrocoagulation after loop excision of the tumor do not allow us to speak about the complete safety of the method due to the rather wide spread of electric current from the application zone, the vast heating zone of the intestinal tissues, which creates the danger of coagulation damage to the deep layers of the intestinal wall with the possibility of its perforation $[5,6]$. More preferable in this regard is the possibility to use high-intensity laser radiation for coagulation and vaporization of colon polyps [7, 8]. At the same time, in the literature, one can find discrepancies when using various parameters 
of laser radiation for the destruction of intraluminal tumors of the colon, there is no unified methodology for the safe use of various laser systems for endoscopic devitalization of epithelial neoplasms [9-13]. In many respects, the differences take place due to the fact that a number of experimental studies were carried out on a non-vascularized section of the intestine (after its resection) or in the condition of an open operation (after enterotomy), as well as on pathological material. We have not found literature sources in which the development of the laser coagulation of the colon was performed in conditions as close as possible to clinical conditions (during intraluminal endoscopy).

\section{- PURPOSE OF THE STUDY}

To evaluate the coagulating properties of various parameters of highintensity laser radiation with a wavelength of 1.06-1.34 $\mu \mathrm{M}$ in animal testing, to work out the optimal modes of safe intraluminal laser exposure to the rectal and colon mucosa in animal testing.

\section{- MATERIALS AND METHODS}

The experimental part of the research was carried out at the Department of General, Private and Operative Surgery and Microbiology of the Vitebsk State Academy of Veterinary Medicine (Vitebsk State Academy of Veterinary Medicine). The study was conducted using 10 male rabbits in the age group from 2 to 2.5 years (median 2.2 years, interquantile latitude from 2.1 years to 2.3 years), live weight from 2.0 to $3.0 \mathrm{~kg}$ (median $2.4 \mathrm{~kg}$, interquantile latitude from 2.1 to $2.6 \mathrm{~kg}$ ). By the method of random distribution ("envelope method"), the animals were divided into two groups of 5 animals each, comparable by) sex, weight and age $(p<0.05)$. In dynamics, the external signs, behavioral and nutritional activity of the animals were assessed. An experimental assessment of various modes of intraluminal exposure of laser radiation of individual parameters to the wall of the rectum and sigmoid colon in vivo has been carried out. The depth of lesion of the intestinal wall in a rabbit was studied depending on the power of laser radiation at a fixed (constant) exposure time ( $t=2 \mathrm{sec}$.). The experiment was carried out under intravenous anesthesia (sol. xylozini $2 \% 0.2 \mathrm{ml}$ per kilogram of animal body weight). Animals of group $1(n=5)$ were exposed to a laser with a wavelength of $1.34 \mu \mathrm{m}(\mathrm{L}-1.34 \mu \mathrm{m})$. In group 2 animals $(n=5)$, exposure on the colon mucosa was performed with a laser with a wavelength of $1.06 \mu \mathrm{m}$ (L-1.06 $\mu \mathrm{m})$. A laser apparatus ("Mediola-Endo" model Fotek LK-50) was used. The large intestine was prepared in advance (hunger for a day). In animal lateral position an endoscope (EC-3890 LZi endoscope with a Pentax i7010 K10 processor) was inserted into the rectum (Fig. 1).

A laser light guide was passed through its biopsy channel of the endoscope.

A local laser exposure on the mucous membrane was performed with a power of 10,15 , and $20 \mathrm{~W}$ in the area of the rectum and sigmoid colon. The diameter of the optical fiber is $1 \mathrm{~mm}$. (1F.600.SMA remote light guide, at a distance of 9-12 $\mathrm{mm}$ to the object, the diameter of the light spot is $\sim 1.5 \mathrm{~mm}$ ). The first exposure site was located at a distance of $2 \mathrm{~cm}$ from the anus. Subsequent foci were staggered at a distance of $2 \mathrm{~cm}$ from each other. The animals were monitored for three days. Behavior, water schedule, 


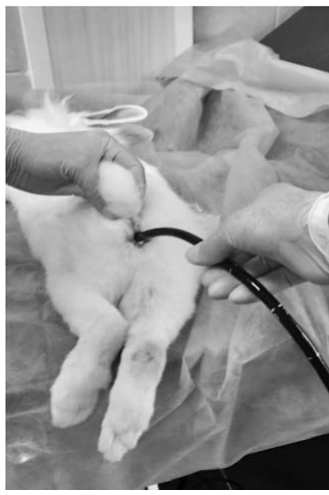

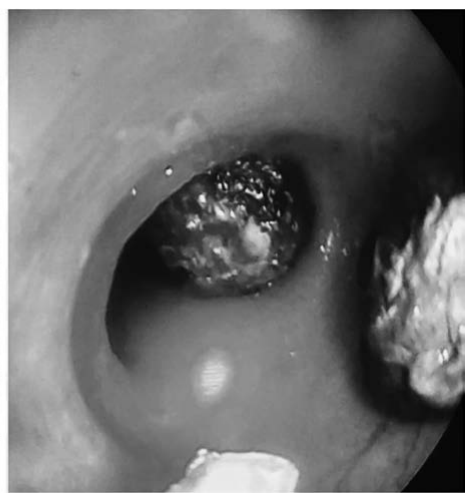

b

Fig. 1. Conducting colonoscopy in a rabbit: $\mathbf{a}$ - insertion of the endoscope into the rectum; $\mathbf{b}$ - lumen of the rabbit rectum

temperature reaction were noted. On the 4 th day the rabbits were taken out of the experiment (euthanasia was carried out by intravenous administration of an excess amount of thiopental sodium). After resection of the intestine with the sites of exposure, gross specimen, including the removed internal organs (liver, kidneys, heart, spleen, lungs, brain), were placed in separate vials with formalin (Fig. 2).

Sections of the small and large intestine of experimental animals were fixed in formalin, washed, transferred to alcohol of increasing concentration, and embedded in paraffin.

Sections 3-4 $\mu \mathrm{m}$ thick were cut from paraffin blocks, the latter were dewaxed with xylene, stained with hematoxylin and eosin, and placed under a cover glass with a balsam. At the light-optical level, when studying histological preparations using a Zeiss microscope (magnification $\times 50$, $\times 100, \times 200, \times 300$ and $\times 400$ ), morphological changes were assessed, while a mathematical analysis of the depth of the intestinal wall lesion was performed depending on the mode of laser exposure.

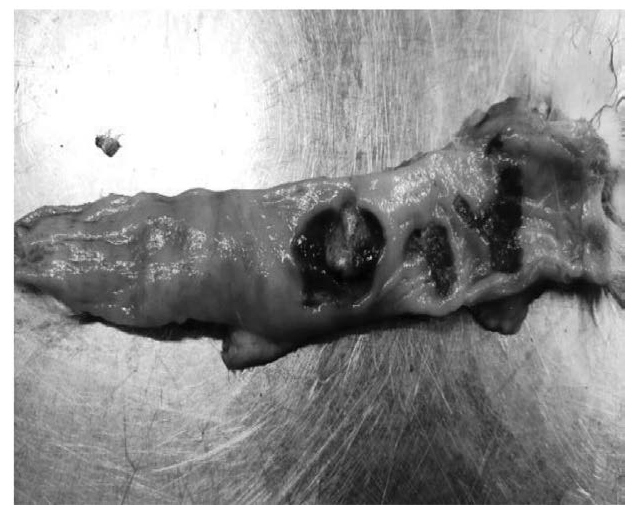

Fig. 2. Gross specimen of rabbit colon with mucosal defects after laser exposure 
Areas of the small and large intestines of experimental animals were fixed in formalin, washed, passed through alcohols of increasing concentration, and embedded in paraffin. Sections 3-4 $\mu \mathrm{m}$ thick were cut from paraffin blocks, the latter were dewaxed with xylene, stained with hematoxylin and eosin, and placed under a cover glass with a balsam. At the light-optical level, when studying histological preparations using a Zeiss microscope (magnification $\times 50, \times 100, \times 200, \times 300$ and $\times 400$ ), morphological changes were assessed, while a mathematical analysis of the depth of the intestinal wall lesion was performed depending on the mode of laser exposure...

To assess the changes, nonparametric methods of statistical analysis were used. The data obtained are presented as median and interquartile interval. Comparison of the research results was carried out using the methods of nonparametric statistics (Mann - Whitney, Fisher). To compare the reliability of changes in the frequencies of the trait in two independent groups, $X^{2}$ was used with Yates' correction for continuity. The results were considered statistically significant at $p<0.05$.

All animals were kept on a standard vivarium diet. Experimental studies were carried out in full compliance with modern principles and bioethics standards, including the "European Convention for the Protection of the Rights of Vertebrate Animals used in Experiments and for Other Scientific Purposes" (1986), "International Recommendations for Biomedical Research Using animals", the CIOMS Ethical guidelines (1985), "Universal Declaration of Animal Rights" adopted by the International League for Animal Rights on 23 September 1977 in London and announced on October 15, 1978 at the headquarters of UNESCO in Paris), Directive 2010/63 / EU of the European Parliament and the Council of the European Union of 22 September 2010 on the protection of animals used for scientific purposes, as well as the conclusion of the Ethical committee of the Vitebsk State Academy of Veterinary Medicine.

\section{- RESULTS AND DISCUSSION}

With an output power of $20 \mathrm{~W}$ remote exposure of laser radiation L-1.34 $\mu \mathrm{m}$ and L-1.06 $\mu \mathrm{m}$ led to the phenomenon of "boiling" with simultaneous wrinkling and mucous membrane destruction, which contributes to the formation of tissue defects in the affected area. The severity of these changes at an output power of $15 \mathrm{~W}$ decreased until the appearance of superficial tissue defects from the side of the mucous membrane without changes of the surrounding tissues in the form of "white" edema and infiltration. At a laser output power of $10 \mathrm{~W}$, all changes were superficial.

The behavior and general condition of the animals did not change after the procedure, their body temperature was $38.6 \pm 1.5^{\circ} \mathrm{C}$.

External changes were comparable during a macroscopic assessment of the defects of the mucous membrane of the large intestine of rabbits, obtained after the exposure of laser with a wavelength of $1.34 \mu \mathrm{m}$ and a wavelength of $1.06 \mu \mathrm{m}$. The dimensions of mucous membrane defects $(\mathrm{cm})$ after destruction of the mucous membrane by the L-1.34 $\mu \mathrm{m}$ laser for two seconds at a power of $10 \mathrm{~W}$ were $0.7(0.6-0.7) \mathrm{cm}$, at a power of $15 \mathrm{~W}-0.8$ $(0.7-0.8) \mathrm{cm}$, at a power of $20 \mathrm{~W}-0.9(0.8-0.9) \mathrm{cm}$ (Table 1$)$. 
Table 1

Dimensions of the defects in the colon mucosa after endoscopic laser exposure on colon mucosa with the wavelength of $1.34 \mu \mathrm{m}$ (exposure of 2 seconds), $\mathrm{cm}$

\begin{tabular}{|l|l|l|l|}
\hline $\begin{array}{l}\text { Animal, } \\
\text { no. }\end{array}$ & Laser power $(\mathbf{W})$ & $\mathbf{2 0}$ \\
\hline 1 & $\mathbf{1 0}$ & $\mathbf{1 5}$ & 0.9 \\
\hline 2 & 0.7 & 0.8 & 0.8 \\
\hline 3 & 0.6 & 0.7 & 0.8 \\
\hline 4 & 0.7 & 0.7 & 0.9 \\
\hline 5 & 0.6 & 0.8 & 1.0 \\
\hline
\end{tabular}

\section{Table 2}

Dimensions of the defects in the colon mucosa after endoscopic laser exposure on colon mucosa with the wavelength of 1,06 $\mu \mathrm{m}$ (exposure of 2 seconds), $\mathrm{cm}$

\begin{tabular}{|l|l|l|l|}
\hline \multirow{2}{*}{$\begin{array}{l}\text { Animal, } \\
\text { no. }\end{array}$} & Laser power $(\mathbf{W})$ & $\mathbf{2 0}$ \\
\hline 1 & $\mathbf{1 0}$ & $\mathbf{1 5}$ & 1.0 \\
\hline 2 & 0.8 & 0.9 & 0.9 \\
\hline 3 & 0.7 & 0.8 & 0.8 \\
\hline 4 & 0.7 & 0.7 & 0.9 \\
\hline 5 & 0.6 & 0.8 & 1.0 \\
\hline
\end{tabular}

Dimensions of the defects in the colon mucosa $(\mathrm{cm})$ after laser vaporization $\mathrm{L}-1.06$ microns during two seconds at the power of $10 \mathrm{~W}$ were $0.7(0.7-0.8) \mathrm{cm}$, at the power $15 \mathrm{~W}-0.8(0.8-0.9) \mathrm{cm}$, at the power $20 \mathrm{~W}-0.9$ $(0.9-1.0) \mathrm{cm}$ (Table 2).

The study helped to determine the average sizes of the resulting mucosal defects: after laser exposure L-1.34 $\mu \mathrm{m}$ for two seconds at a power of $10 \mathrm{~W}$, its amounted to $0.7(0.6-0.7) \mathrm{cm}$, after laser exposure L- $1.06 \mu \mathrm{m}$ of the same parameters $-0.7(0.7-0.8) \mathrm{cm}$. The average size of laser radiation defects L-1.34 $\mu \mathrm{m}$ for two seconds at a power of $15 \mathrm{~W}$ was $0.8(0.7-0.8) \mathrm{cm}$, laser radiation L-1.06 $\mu \mathrm{m}$ of the same parameters $-0.8(0.8-0.9) \mathrm{cm}$. After exposure to laser radiation L-1.34 $\mu \mathrm{m}$ for two seconds at a power of $20 \mathrm{~W}$, the average defect size in the mucous membrane of the colon was $0.9(0.8-$ $0.9) \mathrm{cm}$, laser radiation $\mathrm{L}-1.06 \mu \mathrm{m}$ of the same parameters $-0.9(0.9-1.0) \mathrm{cm}$.

Histological examination of the colon wall after laser exposure L-1.34 $\mu \mathrm{m}$ with a power of $10 \mathrm{~W}$ (Fig. 3) revealed neutrophil infiltration, lymphocyte infiltration and eosinophil infiltration of the lamina propria (upper part of the image). Considering the superficial nature of the coagulation lesion of the colon mucosa under this laser exposure, this power and exposure is clearly insufficient for photodestruction of the surface tissues of the colon.

Histological examination of the intestinal wall after laser exposure with L-1.34 $\mu \mathrm{m}$ radiation with a power of $15 \mathrm{~W}$ revealed neutrophil infiltration, lymphocyte infiltration and eosinophils infiltration of tissues at the level of the deep mucosa (up to the level of the muscle layer). In Fig. 4, it is visible at the top of the photo. Since below this level muscular and serous layers of the intestine with this mode of exposure are not involved in the inflammatory and destructive process, these parameters of radiation L-1.34 $\mu \mathrm{m}$ can be considered optimal (safe in terms of excluding the possibility of intestinal perforation). 


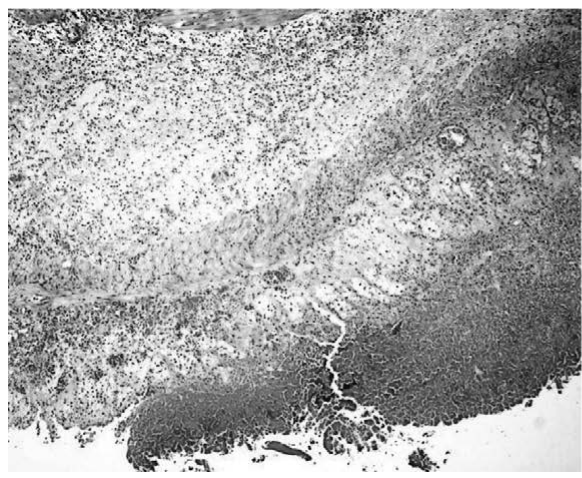

a

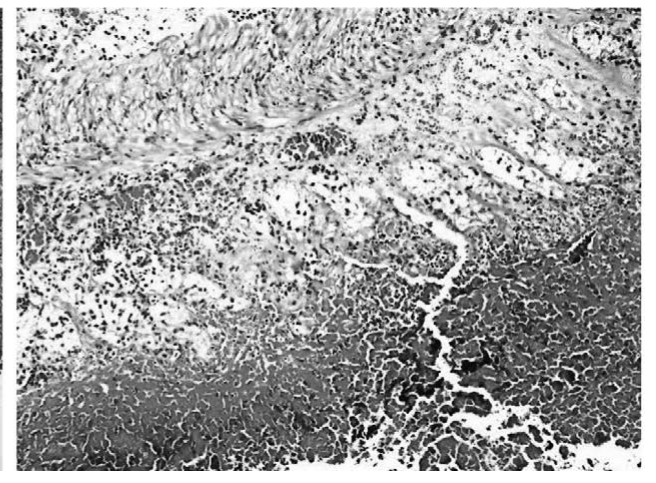

b

Fig. 3. Superficial necrosis of the colon mucosa (with bright pink staining in the lower part of the histogram) 3 days after laser exposure to L-1.34 $\mu \mathrm{m}$. with the power of $10 \mathrm{~W}$. Staining with hematoxylin and eosin $(a-$ increase $\times 125, b-$ increase $\times 250)$

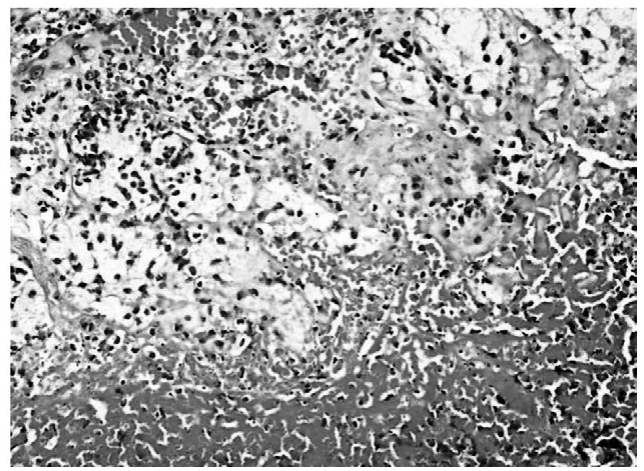

Fig. 4. Superficial necrosis of the colon mucosa (with bright pink staining in the lower part of the histogram) 3 days after laser exposure to L-1.34 $\mu \mathrm{m}$ with the power of $15 \mathrm{~W}$. Stained with hematoxylin and eosin. Increase $\times 500$

Histological examination of the intestinal wall after laser exposure with L-1.34 $\mu \mathrm{m}$ with a power of $20 \mathrm{~W}$ revealed total necrosis of the mucous membrane (the latter is visualized as total necrotic detritus with small areas of glands). In the muscle plate, there is abundant infiltration of lymphoid cells. The muscular membrane of the intestine is swollen, edematous, fragmented in some areas and is in a state of lysis (Fig. 5).

In the process of histological study of the results of laser exposure L-1.06 $\mu \mathrm{m}$ with a power of $10 \mathrm{~W}$, it was found that the morphological picture of damage to the intestinal wall corresponds to that when using radiation $\mathrm{L}-1.34 \mu \mathrm{m}$ with a power of $15 \mathrm{~W}$, and the results of a histological study of the effect of this radiation with a power of $15 \mathrm{~W}$ were identical to the effect of radiation $\mathrm{L}-1.34 \mu \mathrm{m}$ with a power of $20 \mathrm{~W}$. That is, reducing the wavelength of laser radiation to $1.06 \mu \mathrm{m}$ increases its damaging capabilities, while the target indicators of optimal (safe) destruction of the mucous membrane provide a radiation power of $10 \mathrm{~W}$. 


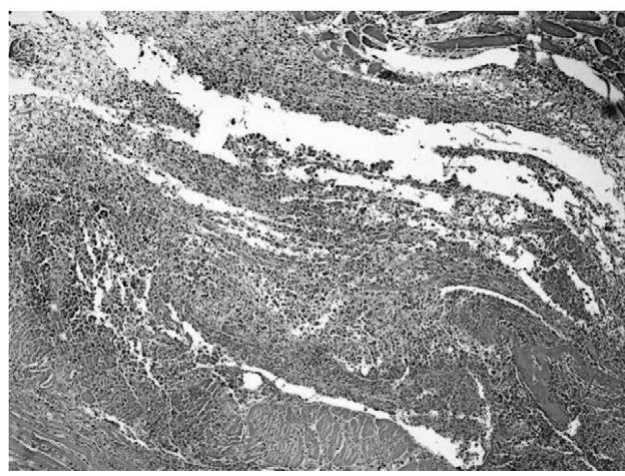

a

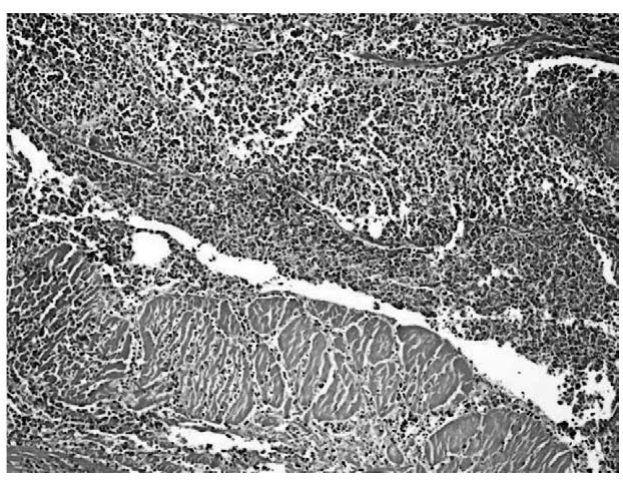

b

Fig. 5. Total necrosis of the colon mucosa (with bright pink staining in the lower part of the histogram) with the signs of destruction and fragmentation of the intestinal muscle layer 3 days after laser exposure to L-1.34 microns with the power of $20 \mathrm{~W}$. Staining with hematoxylin and eosin $(a-$ increase $\times 125, b-$ increase $\times 250$ )

- CONCLUSIONS

1. The data indicate that in colon mucosa at remote exposure of laser radiation with a wavelength of $1.34 \mu \mathrm{M}$, the maximum energy absorption occurs at a radiation power of $20 \mathrm{~W}$ and 2 second exposure. In this case, the depth of the lesion completely captures the mucous membrane (total coagulation necrosis) and spreads to the muscle layer, leading to its partial devitalization and fragmentation. This mode of exposure when performing laser significantly increases the risk of bowel perforation and peritonitis development when performing vaporization of benign colon neoplasms.

2. Reducing the power of remote laser radiation with a wavelength of $1.34 \mu \mathrm{m}$ to $15 \mathrm{~W}$ allows to limit the maximum thermal (coagulating) effect only the mucosa (to the level of the muscular plate of the mucous membrane) without affecting the muscular layer of the intestine. Due to the insufficient coagulating effect of laser radiation with a wavelength of $1.06 \mu \mathrm{m}$ and $1.34 \mu \mathrm{m} 10 \mathrm{~W}$ with a surface effect of destruction of the mucous membrane, the achievement of the target effect on ablation of tumor formation of the mucosa becomes doubtful, dictating the need to increase the radicality of the intervention by increasing the radiation power.

3. In the course of the experiment, it was shown that the dose of laser radiation with a wavelength of $1.34 \mu \mathrm{m}$ (power $15 \mathrm{~W}$, exposure 2 seconds) is sufficient and optimal for the destruction of tumor tissue of the mucous membrane, limiting the zone of destruction only mucous membrane, without thermal damage to the muscular layer of the intestinal membrane.

4. The morphological picture of damage to the intestinal membrane by laser radiation with a wavelength of $1.06 \mu \mathrm{m}$ and a power of $10 \mathrm{~W}$ corresponds to that when using radiation with a wavelength of $1.34 \mu \mathrm{m}$ and a power of $15 \mathrm{~W}$, and the results of a histological study of the 
effect of this radiation with a power of $15 \mathrm{~W}$ are identical to the effect of radiation L-1, $34 \mu \mathrm{m}$ with a power of $20 \mathrm{~W}$. Reducing the wavelength of laser radiation to $1.06 \mu \mathrm{M}$ increases its damaging capabilities, and the target indicators of optimal (safe) mucosa destruction provide a radiation power (output) of $10 \mathrm{~W}$.

Authors' contribution: Buhtarevich S., Denisenko V., Gain Yu. the concept and design of the study; Buhtarevich S. - writing an article; Buhtarevich S., Denisenko V., Gain Yu. - text editing; Buhtarevich S. processing of materials, evaluation of research results; Buhtarevich S. writing a literary review.

Conflict of interest. The authors declare no conflict of interest.

\section{REFERENCES}

1. Orlova L.P., Markova E.V., Marinushkin A.M., Trubacheva Ju.L. (2003) The role of endorectal ultrasound in the diagnosis of malignancy of villous tumors of the rectum. Ultrasound and functional diagnostics, no 1, pp. 11-16.

2. $\quad$ Rivkin V.L., Kirianov I.V., Nikitin A.M., Lukin V.V. (2005) Colon polyps and polyposis. Moscow: Medpraktika-M. (in Russian)

3. Rivkin V.L., Bronshtejn A.S., Fain S.N. (2001) Coloproctology Guide. Moscow: Medicinskaja praktika. (in Russian)

4. Potehin A.V. (2007) Diagnostics and surgical treatment of villous tumors of the colon (PhD Thesis). Moscow: Central Military Clinical Hospital named after A.A. Vishnevsky.

5. Vorobiev G.I. (2002) Laparoscopic surgery in patients with rectal cancer. Practical oncology, vol. 3, no 2, pp. 93-104.

6. Rimonda R. (2013) Transanal minimally invasive surgery (TAMIS) with SILS port versus transanal endoscopic microsurgery (TEM): a comparative experimental study. Surgical endoscopy, vol. 27, no 10, pp. 3762-3768.

7. Caselli G., Ocares M., Caselli B. (2012) Uso del dispositivo SILS en transanal minimamente invasiva para el manejo de lesiones benignas de recto. Revista chilena de cirugia, vol. 64, no 4, pp. 391-394.

8. Albert V. (2013) Transanal minimally invasive surgery (TAMIS) for local excision of benign neoplasms and early-stage rectal cancer: efficacy and outcomes in the first 50 patients. Disease of the colon and rectum, vol. 56, no 3, pp. 301-308.

9. Kulling D., Christ A., Karaaslan N., Fried M., Bauerfeind P. (2001) Is histological investigation of polyps always necessary? Endoscopy, vol. 33, no 5 , pp. 428-432.

10. Goldstein N., Watts J., Neill J., Vogel L., Barkel D., Kadro O., Priest S., Klein S. (2001) The effect of electro-thermal cautery-assisted resection of diminutive colonic polyps on histopathologic diagnosis. American Journal Clinical Pathology, vol. 115, no 3, pp. 356-361.

11. Anichkov N.M. (2005) Atlas of pathology of human tumors. The medicine, $214 \mathrm{p}$.

12. Oono Y., Fu K., Nakamura H., Iriguchi Y. (2009) Progression of a sessile serrated adenoma to an early invasive cancer within 8 months. Dig Dis Sci., vol. 54, no 4, pp. 906-909.

13. Bond J. (2003) Colon polyps and cancer. Endoscopy, vol. 37, no 3, pp. 208-212.

Submitted/Подана: 23.06 .2021

Accepted/Принята: 06.09.2021

Contacts/Контакты: gain@tut.by 